\section{Growing Medium and Fertilization Regime Influence Growth and Essential Oil Content of Rosemary}

\author{
Thomas H. Boyle and Lyle E. Craker \\ Department of Plant and Soil Sciences, University of Massachusetts, \\ Amherst, MA 01003
}

James E. Simon

Department of Horticulture, Purdue University, West Lafayette, IN 47907

Additional index words. container culture, fertilizers, herbs, ornamental plants,

Rosmarinus officinalis

\begin{abstract}
Plants of rosemary [Rosmarinus officinalis L. (Lamiaceae)] were grown in pots containing a soilless ( 1 sphagnum peat :1 perlite) or soil-based $(1$ sphagnum peat : 1 perlite :1 field soil) growing medium and fertilized with either 12N-5.2P-12.5K controlled-release fertilizer (CRF) at $9.0 \mathrm{~g} / \mathrm{pot}$; constant liquid fertilization (LF) with 20N4.3P-16.7 K at $150 \mathrm{mg} \mathrm{N} / \mathrm{liter}$; constant $\mathrm{LF}$ at $150 \mathrm{mg} \mathrm{N} / \mathrm{liter}$, plus $\mathrm{CRF}$ at $4.5 \mathrm{~g} /$ pot; weekly LF at $150 \mathrm{mg} \mathrm{N} /$ liter; or weekly $L F$ at $150 \mathrm{mg} \mathrm{N} / \mathrm{liter}$, plus CRF at $4.5 \mathrm{~g}$ / pot. Constant LF plus CRF generally reduced plant height and depressed shoot fresh weight relative to other fertilizer regimes. Essential oil content was highest in plants receiving weekly LF. Plants grown in the soil-based mix were shorter, shoot fresh and dry weight tended to be lower, and essential oil yield was higher when compared to plants grown in the soilless mix. Satisfactory growth was obtained in both media when rosemary plants were fertilized with $12 \mathrm{~N}-5.2 \mathrm{P}-12.5 \mathrm{~K}$ CRF at $9.0 \mathrm{~g} / \mathrm{pot}$ or weekly LF with $20 \mathrm{~N}<.3 \mathrm{P}-16.7 \mathrm{~K}$ at $150 \mathrm{mg} \mathrm{N} / \mathrm{liter}$.
\end{abstract}

Rosemary is an evergreen, perennial shrub that is endemic to the Mediterranean region and has been cultivated since ancient times (Simon et al., 1984). The aromatic, resinous leaves are used for culinary flavoring, and oil distilled from leaves and flowering shoots is used in perfumery and medicine (Liberty Hyde Bailey Hortorium, 1976). Rosemary shows commercial potential as a dual-purpose foliage and culinary potted plant (DeBaggio and Boyle, 1988). Marketablesize potted plants can be produced in 4 to 6 months from propagation by cuttings (DeBaggio, 1987).

Research to determine the influence of growing media and fertilization on the growth and essential oil content of aromatic herbs appears to be lacking. We are unaware of any reports on the effect of growing media or fertilization practices on growth of rosemary under protected cultivation (Simon et al., 1984). The following experiment was initiated to determine the influence of growing media and fertilization regimes on the growth and essential oil content of potted rosemary.

Shoot-tip cuttings ( 7.5 to $10 \mathrm{~cm}$ long) were propagated under intermittent mist on 8 June 1987. The propagation medium was a $1: 1$ (v/v) combination of Pro-Mix BX (Premier Brands, New Rochelle, N.Y.) and perlite

\footnotetext{
Received for publication 27 Dec. 1989. Publication no. 3003 of the Massachusetts Agricultural Experiment Station. The cost of publishing this paper was defrayed in part by the payment of page charges. Under postal regulations, this paper therefore must be hereby marked advertisement solely to indicate this fact.
}

maintained at 21 to $24 \mathrm{C}$ by bottom heat. On 29 June, rooted cuttings were pruned by removing $\approx 1 \mathrm{~cm}$ of the shoot apices; then plants were potted in 0.14-liter plastic containers (one plant per pot) using Pro-Mix BX. Plants were fertilized one to three times weekly with $20 \mathrm{~N}-4.3 \mathrm{P}-16.7 \mathrm{~K}$ at $150 \mathrm{mg} \mathrm{N} / \mathrm{liter}$ from 7 July to 28 Aug. Plants were transplanted on 28 Aug. into 1.90-liter plastic pots (one plant per pot) filled with either a soilless [ 1 sphagnum peat $: 1$ perlite $(\mathrm{v} / \mathrm{v})]$ or soil-based [1 sphagnum peat $: 1$ perlite $: 1$ field soil (by volume)] growing medium. The field soil was a coarse-loamy, mixed, mesic Typic Fragiochrept that was steam-pasteurized $(\approx 80 \mathrm{C}$ minimum for 30 rein) before mixing. Both media were amended with $5.93 \mathrm{~kg}$ dolomitic limestone $/ \mathrm{m}^{3}$. On 29 Aug., plants were pruned as described above and fertilization regimes were initiated. The fertilization regimes were: 1) Sierra $12 \mathrm{~N}-5.2 \mathrm{P}-12.5 \mathrm{~K}$ (Sierra Chemical, Milpitas, Calif.) controlled-release fertilizer (CRF) at $9.0 \mathrm{~g} / \mathrm{pot}$; 2) liquid fertilization (LF) using Peters 20N-4.3P-16.7K (Peters at $150 \mathrm{mg} \mathrm{N} /$ liter at every watering; 3) LF applied at every watering at $150 \mathrm{mg}$ N/liter plus CRF at $4.5 \mathrm{~g}$ /pot; 4) LF once each week at $150 \mathrm{mg} \mathrm{N} /$ liter; 5) or LF once each week at $150 \mathrm{mg} \mathrm{N} /$ liter, plus $\mathrm{CRF}$ at $4.5 \mathrm{~g} /$ pot. CRF was applied as a one-time top dressing at the start of the experiment. A 1:100 fertilizer injector was used for LF applications. Pots were spaced on $25-\mathrm{cm}$ centers from the start of the fertilization regimes until harvest. There were eight replications (pots) per treatment and treatments were completely randomized on the greenhouse bench.

Plants were grown in a glasshouse at the Fertilizer Products, Fogelsville, Pa.) applied
Univ. of Massachusetts, Amherst ( $42^{\circ} 22.5^{\prime}$ $\mathrm{N}$ latitude). Glasshouse temperature setpoints were 18/24C (night temperature/vent) during the experiment; the temperatures ranged from 16 to $39 \mathrm{C}$. Plants were watered one to three times weekly during the experiment to maintain adequate moisture in the growing media.

Bulk density and cation-exchange capacity were determined for both growing media using standard procedures (Blake, 1965; Chapman, 1965). Extracts of a 1 growing medium : 2 deionized water (v/v) mixture were used for soluble salt and $\mathrm{pH}$ tests (Peterson, 1982). Porosity measurements were obtained using 4-cm-diameter glass columns filled with $14 \mathrm{~cm}$ of growing medium. Total porosity was defined as the ratio of the saturated medium water volume to the growing medium volume ( $x$ 100). Maximum water capacity was defined as the ratio of the drained medium water volume to the growing medium volume ( $\mathrm{x} 100$ ). Aeration porosity was defined as the difference between total porosity and maximum water capacity. Physical and chemical analyses were performed at the experiment initiation using five replicate samples of each growing medium per analysis.

Plants were harvested on 3 Dec., and data were collected on plant height (base of plant to apex of longest shoot) and shoot fresh weight. Shoots were dried to constant weight (40C for 7 days) and then reweighed. Foliage was removed from each replicate plant, and tissue samples were ground to pass a 20mesh screen. Essential oils were extracted from tissue samples ( 35 to $65 \mathrm{~g}$ ) by hydrodistillation for $1 \mathrm{hr}$ with a modified clevenger trap (ASTA, 1968).

Physical and chemical properties of the two growing media differed significantly (Table 1). Bulk density, cation exchange capacity, maximum water capacity, $\mathrm{pH}$, and soluble salt content were greater for the soilbased mix compared to the soilless mix. Total and aeration porosity were considerably higher in the soilless mix than in the soilbased mix.

Fertilization practices had a significant effect on plant height and fresh weight of rosemary (Table 2). Plants receiving constant LF plus CRF were shorter than plants under any other fertilization regime, except for CRF only. In addition, constant LF plus CRF depressed shoot fresh weight relative to other fertilizer treatments. Constant LF plus CRF tended to reduce dry matter accumulation compared to other fertilization regimes, although not significantly, $(\approx 12$ vs. 14 to 16 g). Bell and Coorts (1979) observed that lemon balm (Melissa oficinalis), peppermint (Mentha $\times$ piperata), and sage (Salvia officinalis) plants that were fertilized weekly with $20 \mathrm{~N}-8.7 \mathrm{P}-16.7 \mathrm{~K}$ at $300 \mathrm{mg} \mathrm{N} / \mathrm{liter}$ were taller and higher in fresh and dry weight than plants fertilized weekly with $20 \mathrm{~N}-8.7 \mathrm{P}-16.7 \mathrm{~K}$ at either 50, 100, or $200 \mathrm{mg}$ N/liter. In our study, rosemary plants were shortest and lowest in fresh weight at the highest fertilization rate (constant LF plus CRF), suggesting that this rate of fertilization suppressed 


\begin{tabular}{|c|c|c|c|c|c|c|c|}
\hline Medium & $\mathrm{pH}$ & $\begin{array}{c}\text { Conductivity } \\
\left(\mathrm{dS} \cdot \mathrm{m}^{-1}\right)\end{array}$ & $\begin{array}{c}\text { Bulk } \\
\text { density } \\
\left(\mathrm{g} \cdot \mathrm{cm}^{-3}\right)\end{array}$ & $\begin{array}{c}\text { Cation } \\
\text { exchange } \\
\text { capacity } \\
\left(\text { meq } / 100 \mathrm{~cm}^{3}\right)\end{array}$ & $\begin{array}{c}\text { Total } \\
\text { porosity } \\
(\% \text { vol })\end{array}$ & $\begin{array}{l}\text { Aeration } \\
\text { porosity } \\
(\% \text { vol })\end{array}$ & $\begin{array}{c}\text { Maximum } \\
\text { water } \\
\text { capacity }^{2} \\
(\% \text { vol })\end{array}$ \\
\hline Peat : perlite & 5.9 & 0.09 & 0.11 & 4.3 & 64.6 & 30.7 & 33.9 \\
\hline Peat : perlite : soil & 6.1 & 0.15 & 0.46 & 10.2 & 56.1 & 12.3 & 43.8 \\
\hline Significance & $*$ & $* *$ & $* * *$ & $* * *$ & $*$ & $* *$ & $*$ \\
\hline
\end{tabular}

${ }^{2}$ Porosity measurements determined using $14-\mathrm{cm}$ columns of growing media.

Significant at $P=0.05,0.01$, or 0.001 , respectively, by $t$ tests. Five replications per medium.

Table 2. Influence of growing medium and fertilization regime on growth and essential oil content of Rosmarinus officinalis.

\begin{tabular}{|c|c|c|c|}
\hline \multirow[b]{2}{*}{ Variable } & \multicolumn{3}{|c|}{ Plant characteristic ${ }^{2}$} \\
\hline & $\begin{array}{c}\mathrm{Ht} \\
(\mathrm{cm})\end{array}$ & $\begin{array}{l}\text { Fresh } \\
\text { wt } \\
(\mathrm{g})\end{array}$ & $\begin{array}{l}\text { Essential } \\
\text { oil content } \\
(\% \pm \mathrm{SE})\end{array}$ \\
\hline \multicolumn{4}{|l|}{ Fertilization regime $^{y}$} \\
\hline LF weekly & $39.0 \mathrm{a}^{\mathrm{y}}$ & $74.7 \mathrm{a}$ & $2.50 \pm 0.08$ \\
\hline LF weekly + CRF, $4.5 \mathrm{~g} /$ pot & $37.1 \mathrm{a}$ & $70.1 \mathrm{a}$ & $2.36 \pm 0.06$ \\
\hline LF constant & $38.9 \mathrm{a}$ & $68.5 \mathrm{a}$ & $2.31 \pm 0.04$ \\
\hline $\mathrm{LF}$ constant $+\mathrm{CRF}, 4.5 \mathrm{~g} / \mathrm{pot}$ & $33.0 \mathrm{~b}$ & $50.2 \mathrm{~b}$ & $2.31 \pm 0.13$ \\
\hline CRF, $9.0 \mathrm{~g} / \mathrm{pot}$ & $35.6 \mathrm{ab}$ & $73.1 \mathrm{a}$ & $2.24 \pm 0.09$ \\
\hline \multicolumn{4}{|l|}{ Growing medium } \\
\hline Peat : perlite & $38.2 \mathrm{a}$ & $71.5 \mathrm{a}$ & $2.27 \pm 0.07$ \\
\hline Peat : perlite : soil & $35.5 \mathrm{~b}$ & $63.6 \mathrm{a}$ & $2.41 \pm 0.03$ \\
\hline \multicolumn{4}{|l|}{ Significance } \\
\hline Fertilization $(\mathrm{F})$ & ** & $* *$ & $\cdots$ \\
\hline Growing medium (M) & $*$ & NS & $\cdots$ \\
\hline$F \times G$ & NS & NS & $\cdots$ \\
\hline
\end{tabular}

${ }^{2}$ Mean separation within main effects within columns by Duncan's multiple range test, $P=0.05$. None of the variables significantly affected dry weight.

${ }^{y} \mathrm{LF}=$ constant and weekly fertilization using $20 \mathrm{~N}-4.3 \mathrm{P}-16.7 \mathrm{~K}$ as a liquid feed at $150 \mathrm{mg} \mathrm{N} / \mathrm{liter}$. $\mathrm{CRF}=12 \mathrm{~N}-5.2 \mathrm{P}-12.5 \mathrm{~K}$ controlled-release fertilizer applied to the media at the start of experiments. Not significant or significant at $P=0.05$ or 0.01 , respectively.

growth of potted rosemary. The specific cause of growth suppression was not determined, but could have been due in part to high salinity or nutrient imbalance.

Many container-grown ornamental crops exhibit enhanced growth and increased plant quality in response to LF and CRF combined, compared to exclusive use of LF or CRF (Maynard and Lorenz, 1979), In our experiment, there were no significant differences in growth between CRF alone at 9.0 g/pot, weekly LF plus CRF at $50 \%$ of the recommended rate $(4.5 \mathrm{~g} / \mathrm{pot})$, or LF applied weekly or at every watering (Table 2).

Plants grown in the soil-based mix were significantly shorter than plants grown in the soilless mix (Table 2). In addition, shoot fresh and dry weight tended to be lower among plants grown in the soil-based mix relative to plants grown in the soilless mix, but the difference was not significant. Bell and Coorts (1979) obtained similar results for lemon balm, peppermint, and sage produced in soilless and soil-based media.

Plants grown in the soilless mix required more frequent irrigations than those in the soil-based mix (data not shown). The need for a higher frequency of irrigation for the soilless medium likely was due to its lower water-holding capacity (Table 1). Lower water-holding capacity in the soilless mix was probably caused by higher levels of noncapillary pore space due to the greater proportion of perlite in the medium. According to Bailey (1927), rosemary is common on calcareous hillsides in southern France and thrives on well-drained soils. Reduced waterholding capacity and increased porosity may have been responsible for the slight enhancement of growth obtained in the soilless mix (Table 2).

Essential oil content was highest in plants receiving the lowest rate of fertilization, i.e., weekly LF (Table 2). These results suggest that high rates of fertilization suppress essential oil biosynthesis in rosemary. Yield of essential oil was higher in plants grown in the soil-based growing medium than in those grown in the soilless medium (Table 2). Fertilization practices, however, exerted a greater influence on essential oil content than growing media.

This study indicates that container-grown rosemary can be produced using low rates of fertilization, i.e., with $12 \mathrm{~N}-5.2 \mathrm{P}-12.5 \mathrm{~K}$ CRF as the sole source of fertilizer or with $20 \mathrm{~N}$ 4.3P-16.7K LF once each week at $150 \mathrm{mg}$ N/liter (Table 2). These two fertilizer re- gimes will result in plants that are similar in size or larger than plants grown at higher levels of fertilization, and they will reduce the potential for groundwater pollution arising from excessive fertilization. Both soilless and soil-based growing media are suitable for production of potted rosemary when fertilization and irrigation practices are controlled.

\section{Literature Cited}

ASTA. 1968. Official analytical methods of the American Spice Trade Association. ASTA, Englewood Cliffs, N.J. p. 8-11.

Bailey, L.H. 1927. The standard cyclopedia of horticulture, vol. 3. New ed. Macmillan, New York.

Bell, S.M. and G.D. Coorts. 1979. The effects of growth mediums on three selected herb species. Florists' Rev. 163:48-49.

Blake, G.R. 1965. Bulk density, p. 374-390. In: C.A. Black, D.D. Evans, L.E. Ensminger, J.L. White, and F.E. Clark (eds.). Methods of soil analysis. Part 1. Physical and mineralogical properties, including statistics of measurement and sampling. Amer. Sot. Agron., Madison, Wis.

Chapman, H.D. 1965. Cation-exchange capacity, p. 891-901. In: C.A. Black, D.D. Evans, L.E. Ensminger, J.L. White, and F.E. Clark (eds.). Methods of soil analysis. Part 2. Chemical and microbiological properties. Amer. Soc. Agron., Madison, Wis.

DeBaggio, T. 1987. Growing rosemary as a holiday pot plant at Christmas, p. 91-95. In: J.E. Simon and L. Grant (eds.). Proc. 2nd Natl. Herb Growers Mktg. Conf. Purdue Univ. Agr. Expt. Sta. Bul. no. 530

DeBaggio, T. and T. Boyle. 1988. Rosemary. GrowerTalks 52(4):16, 18.

Liberty Hyde Bailey Hortorium. 1976. Hortus third: A concise dictionary of plants cultivated in the United States and Canada. 3rd ed. Macmillan, New York.

Maynard, D.N. and O.A. Lorenz. 1979. Controlled-release fertilizers for horticultural crops. Hort. Rev. 1:79-140.

Peterson, J.C. 1982. Monitoring and managing fertility-Part II. Monitoring $\mathrm{pH}$ and soluble salts levels in growing media. Ohio Florists' Assn. Bul. 630:3-4.

Simon, J. E., A.F. Chadwick, and L.E. Craker. 1984. Herbs: an indexed bibliography, 19711980. The scientific literature on selected herbs, and aromatic and medicinal plants of the temperate zone. Archon, Hamden, Corm. 